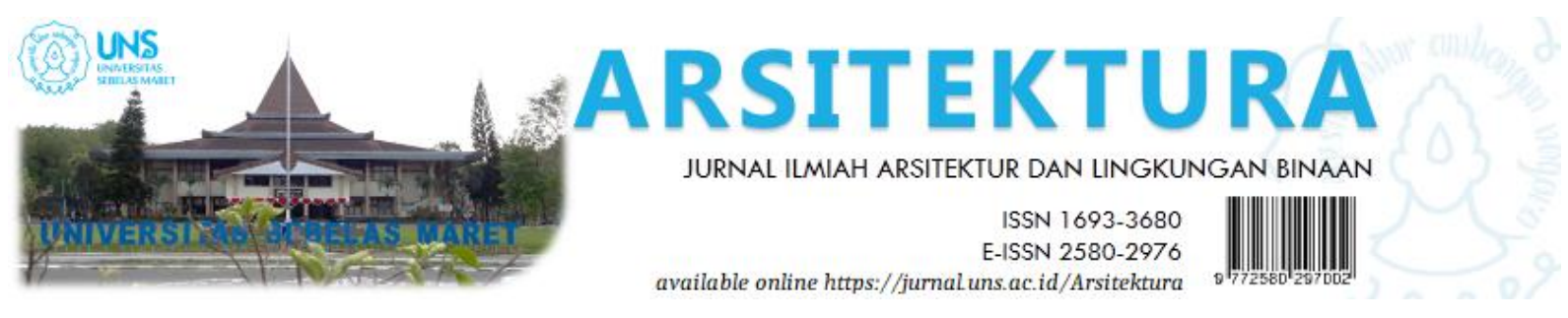

Volume 19 Issue 1 April 2021, pages:95-106

\title{
Kesiapan Public Space di Kota Pontianak Menghadapi Kondisi New Normal Pasca Covid 19
}

\author{
Public Space Readiness inn Pontianak \\ to Anticipate New Normal Post Covid 19
}

\author{
Chandra Bayu ${ }^{1 *}$, Fery Kurniadi ${ }^{2}$ \\ Program Studi D4 Desain Ka wasan Binaan, Jurusan Teknik Arsitektur, Politeknik Negeri Pontianak ${ }^{1 *}$ \\ cbrch4ndr4@gmail.com \\ Program StudiD4 Desa in Ka wasan Binaan, Jurusan Teknik Arsitektur, Politeknik Negeri Pontianak ${ }^{2}$
}

DOI: https://doi.org/10.20961/arst.v19i1.46450

Received: December 7,2020 Revised: March 26,2021 Accepted: March 28,2021 Available online: April 30,2021

\begin{abstract}
Covid 19 pandemic that strike the world, has had a major impact on changes people's lives. The changes as a result of the application of social distancing, which is done to slow and stop the spread of disease, termed 'NewNormal'. This studyaims to determine changes in socio-spatial conditions on the use and to determine the readiness of public spaces in Pontianak in accommodating thenew normal. In addition, the results of this study will contribute ideas related to the development of learning in designing public spaces in the future. Mix Method approach has been used. Importance and performance analysis have been used to analyze the quantitative datas and the qualitative data has been observed by place centered mapping. By comparing the quantitative and qualitative output, the result show the public space readiness indicator are: all public spaces with good performance in accommodating recreational and social activities; two public space with good performance in accommodating sport activities; The need to improved 'health protocols' control and WASH; recessive' mechanism in apply physical distancing; inconsistency of Expectation-Behavior; and unimportance of the tele-working / tele-learning.
\end{abstract}

Keywords : public space, new normal, covid 19, socialdistancing, importance performance analysis

\section{PENDAHULUAN}

Kondisi penyebaran wabah Covid 19 memberikan dampak yang besar bagi kehidupan masyarakat. Secara Sosial dapat dilihat dari diliburkannya sekolah-sekolah dan kampus-kampus, bekerja dari rumah (WFH), sampai pembatasan aktivitas masyarakat. Seruan menjalankan social distancing, mencuci tangan (WHO, 2020b) dan penggunaan masker di tempat umum (BNPB
RI, 2020). Kemerosotan ekonomi terjadi, jumlah pekerja yang di PHK lebih besar 1,5 juta dengan $90 \%$ dari jumlah tersebut dirumahkan 10\% di-PHK (Hanoatubun, 2020). Pembatasan penggunaan ruang-ruang publik sebagai bagian dari penerapan jaga jarak, menjadi salah satu kebijakan utama yang diterapkan, bahkan oleh setengah populasi dunia. Kita dapat melihat kebanyakan orang di dunia mematuhi anjuran untuk tinggal di 
rumah, sehingga menyebabkan jalan-jalan kota, taman, pantai, plaza, dan kawasan pejalan kaki menjadi kosong (Honey-rosés et al., 2020). Di kota Pontianak sendiri, penerapan pembatasan aktivitas massa di tempat umum juga sangat terasa dampaknya. Ruang-ruang publik yang biasanya ramai oleh masyarakat yang berkumpul atau berolahraga, terlihat sepi. Taman Alun Kapuas bahkan ditutup sementara untuk meminimalisir dan mempersempit ruang gerak penyebaran COVID-19 di wilayah Pontianak (ANTARA, 2020).

Dari kondisi tersebut tentu akan menimbulkan pertanyaan, seperti apa keberlanjutan dari ruang-ruang publik yang ada di Kota Pontianak di masa depan. Akankah ruangruang publik tersebut akan ditinggalkan oleh penggunanya atau masyarakat tetap bersedia menggunakannya dan menyesuaikan diri dengan kondisi new normal di ruang publik, tentu saja akan sangat tergantung terhadap perkembangan permasalahan pandemik Covid 19 ini di masa depan. Perlu antisipasi terhadap dampak perubahan sosio-spasial terkait eksitensi ruang-ruang publik dalam kondisi new normal, sehingga dapat memberikan sumbangan pemikiran terkait pengembangan pembelajaran perancangan ruang publik di masa depan.

\section{METODE}

Penelitian ini akan dilaksanakan selama 6 (enam) bulan. Waktu pelaksanaannya direncanakan dari bulan Juni tahun 2020 sampai dengan bulan November tahun 2020. Sedangkan lokasi penelitiannya adalah beberapa ruang publik kota Pontianak yaitu Taman Alun Kapuas, Taman Catur Untan, Taman Digulis Untan dan Taman Akcaya Kota Baru.

Penelitian ini dilaksanakan dengan mix method dimana pengumpulan dan analisis data kuantitatif yang diikuti pengumpulan dan analisis kualitatif (Creswell, John W; Plano Clark, 2007).

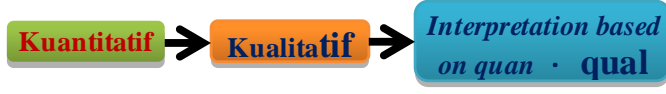

Bagan 1. Explanatory Design

Sumber: (Creswell, John W; Pla no Clark, 2007)
Quesioner disampaikan kepada 100 orang pengguna empat ruang publik utama dikota Pontianak: Taman Alun Kapuas; Taman catur Untan; Taman Digulis Untan; Taman Akcaya. Data tersebut akan dianalisis dengan metode importance performance analysis (IPA) untuk mengukur tingkat harapan dan seperti apa kinerja pelayanan ruang-ruang publik tersebut dari sudut pandang penggunanya. Hasil analisisnya dipetakan didalam kuadran kartesius untuk melihat seperti apa kualitas dari variabel yang diukur.

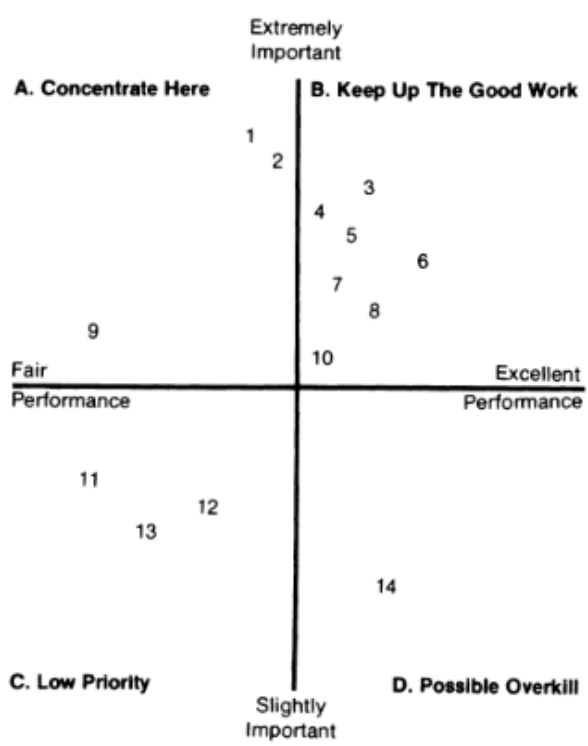

Bagan 2. Importance-Performance Grid Sumber: (Martilla et al., 2010)

Kuadran A menunjukkan Tingkat harapan tinggi tetapi performa masih rendah, upaya peningkatan performa dikonsentrasikan di sini. Kuadran B menunjukkan Tingkat harapan yang tinggi dan performa sudah baik, performa harus dipertahankan. Kuadran C variabel yang tidak terlalu penting dan tingkat performa yang rendah, peningkatan kualtas variabel di kuadran ini dapat ditingkatkan tetapi tidak menjadi prioritas utama. Kuadran D tingkat harapan yang rendah tetapi memiliki performa yang tinggi.

Adapun Parameter yang akan diukur adalah : kualitas desain ruang publik/ taman; ruang publik/ taman untuk peningkatan kualitas kesehatan masyarakat; kualitas pelayanan ruang publik dalam mewadahi pola kerja dengan penerapan social distancing; personal spacel proksemik; dan regulasi Pemerintah. 
Tabel 1. Variabel Penelitian

\begin{tabular}{|c|c|}
\hline PARAMETER & VARIABEL \\
\hline \multirow{5}{*}{$\begin{array}{l}\text { Kualitas desain } \\
\text { ruang publik/ } \\
\text { taman }\end{array}$} & $\begin{array}{l}\text { Kontrol/ cek penggunaan masker, suhu } \\
\text { tubuh di pintu masuk taman }\end{array}$ \\
\hline & $\begin{array}{l}2 \text { Kecukupan dan ketersediaan fasilitas cuci } \\
\text { tangan }\end{array}$ \\
\hline & $\begin{array}{l}3 \text { Kecukupan dan ketersediaan banner/ } \\
\text { signage himbauan penerapan protokol } \\
\text { kesehatan }\end{array}$ \\
\hline & $\begin{array}{l}4 \begin{array}{l}\text { Ukuran/ lebar jalur pejalan kaki/ } \\
\text { trotoar/selasar memungkinkan protokol jaga } \\
\text { jarak }\end{array} \\
\end{array}$ \\
\hline & \begin{tabular}{|l}
5 Desain dan ukuran bangku/ kursi/ tempat \\
duduk memungkinkan protokol jaga jarak
\end{tabular} \\
\hline \multirow{4}{*}{$\begin{array}{c}\text { Ruang publik/ } \\
\text { taman untuk } \\
\text { peningkatan } \\
\text { kualitas kesehatan } \\
\text { masyarakat }\end{array}$} & 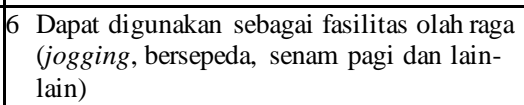 \\
\hline & \begin{tabular}{|l}
$7 \begin{array}{l}\text { Dapat digunakan sebagai fasilitas rekreasi } \\
\text { (bersantai keluarga, sosialisasi, dll) }\end{array}$ \\
\end{tabular} \\
\hline & \begin{tabular}{|l}
8 Memiliki ruang hijau dan vegetasi yang \\
cukup untuk meningkatkan kualitas udara.
\end{tabular} \\
\hline & $\begin{array}{l}\text { Memiliki area yang fleksibel untuk dapat di } \\
\text { ubah/ konversi menjadi fasilitas kesehatan } \\
\text { darurat . }\end{array}$ \\
\hline \multirow{3}{*}{$\begin{array}{l}\text { Kualitas pelayanan } \\
\text { ruang publik dalam } \\
\text { mewadahi pola } \\
\text { kerja dengan } \\
\text { penerapan social } \\
\text { distancing }\end{array}$} & $\begin{array}{l}\text { 10 Terdapat area yang dapat digunakan untuk } \\
\text { belajar/ bekerja secara online di ruang } \\
\text { publik/ taman ini. }\end{array}$ \\
\hline & $\begin{array}{l}\text { 11 Terdapat fasilitas listrik untuk charge } \\
\text { peralatan belajar/ kerja secara online } \\
\text { (laptop/handphone) }\end{array}$ \\
\hline & $\begin{array}{l}\text { 12Terdapat fasilitas sambungan internet gratis } \\
\text { untuk menunjang kegiatan belajar/ kerja } \\
\text { secara online }\end{array}$ \\
\hline $\begin{array}{l}\text { Personal spacel } \\
\text { proksemik }\end{array}$ & $\begin{array}{l}\text { 13 Pembatasan jumlah Pengunjung untuk } \\
\text { menjaga tingkat kepadatan pengunjung }\end{array}$ \\
\hline $\begin{array}{l}\text { Regulasi } \\
\text { Pemerintah }\end{array}$ & $\begin{array}{l}\text { 14Regulasi Pemerintah dalam mengatur } \\
\text { penggunaan Ruang Publik untuk } \\
\text { menghindari penyebaran Covid } 19\end{array}$ \\
\hline
\end{tabular}

Selanjutnya dilakukan pemetaan Perilaku pengguna ruang publik dengan metode Place centered mapping disetiap taman. Selanjutnya dilakukan dialog antara hasil analisis IPA diatas dengan hasil pemetaan Perilaku yang selanjutnya diinterpretasikan secara deskriptif.

\section{HASIL DAN PEMBAHASAN}

\subsection{Diagram IPA Dari Masing-Masing Ruang Publik}

Berdasarkan hasil kuesioner, data dimasukan didalam tabel Skor Kinerja dan Harapan untuk kemudian ditampilkan dalam diagram kartesius untuk melihat posisi kuadran dari masing-masing variabel di setiap Taman. Berikut adalah diagram kartesius dari masingmasing taman.
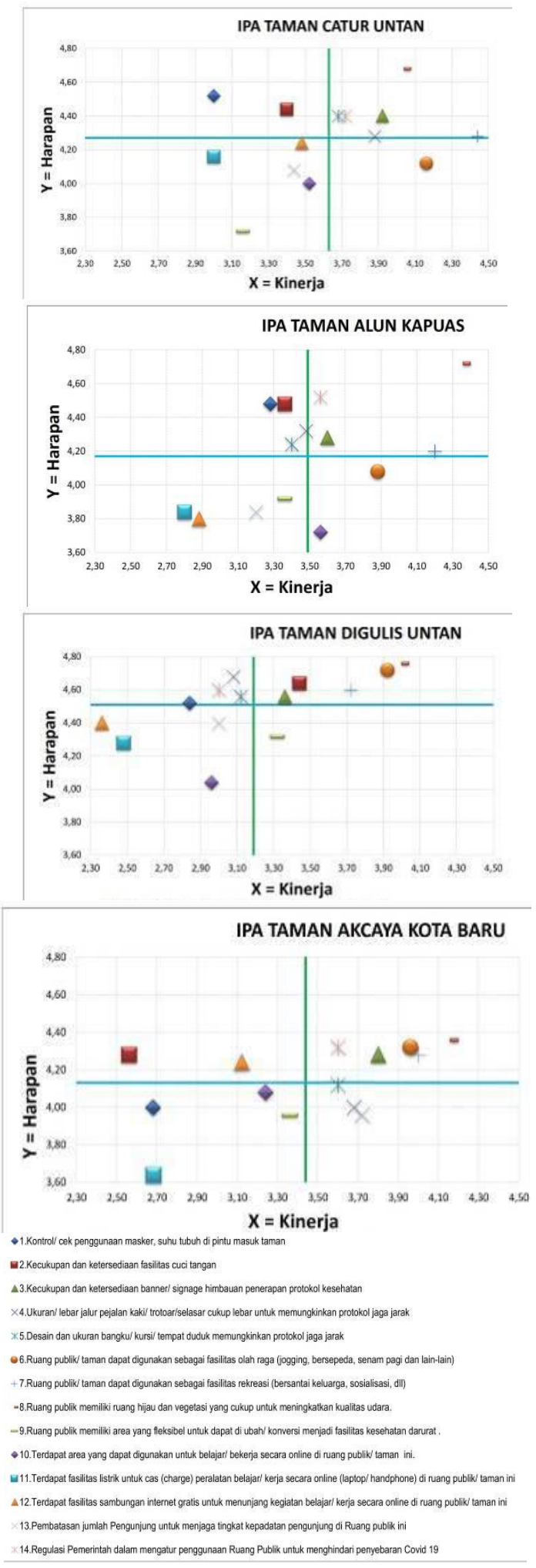

Bagan 3. Diagram IPA Setiap Ruang Publik 


\subsection{Diagram IPA Rata-Rata Keseluruhan Ruang Publik}

Dari hasil penggabungan data keseluruhan taman, kemudian dirangkum dalam tabel Skor Kinerja dan Harapan untuk kemudian ditampilkan dalam diagram kartesius untuk melihat posisi kuadran rata-rata dari masingmasing variabel seluruh Taman. Berikut adalah diagram kartesius dari masing-masing taman.

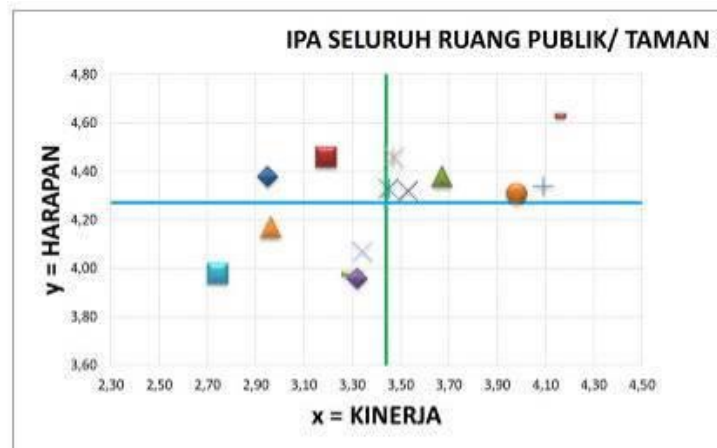

Bagan 4. Diagram IPA Seluruh Ruang Publik

Dari diagram diatas, diketahui bahwa terd apat dua atribut di kuadran A yang menjadi faktor penting yang menentukan kepuasan Pengguna Ruang dan tetapi masih memerlukan peningkatan Kinerja yaitu Kontrol/ cek penggunaan masker, suhu tubuh di pintu masuk taman; Kecukupan dan ketersediaan fasilitas cuci tangan.

Terdapat enam atribut yang penting bagi pengunjung serta telah memiliki performa yang baik yaitu : ketersediaan banner/ signage himbauan; dimensi jalur pejalan kaki/ trotoar/selasar memungkinkan protokol jaga jarak; Desain dan ukuran bangku/ kursi/ tempat duduk memungkinkan protokol jaga jarak; dapat digunakan sebagai fasilitas olah raga; dapat digunakan sebagai fasilitas rekreasi; memiliki ruang hijau dan vegetasi yang cukup untuk meningkatkan kualitas udara; Regulasi Pemerintah untuk menghindari penyebaran Covid 19 di ruang publik.

\subsection{Ruang Publik untuk Aktivitas Sosial dan Olah Raga}

Setiap pengunjung pasti memiliki maksud dan tujuan, untuk apa di adatang ke ruang publik. Ada yang berkunjung untuk sekedar menikmati suasana dan beristirahat (Mua \& Suheri, 2018), berolah raga, bermain, dan aktivitas ekonomi (Pratiwi, 2016). Pengguna ruang publik (area kajian) di kota Pontianak, didominasi tujuan untuk berjalan-jalan/ wisata (63\%) dan berjualan/ berdagang (17\%). Ada pula yang berkunjung untuk aktivitas lainnya. Sehubungan dengan issu Covid 19, dapat dilihat seperti apa harapan dari pengguna ruang publik di Kota Pontianak.

Berdasarkan hasil analisis, aktivitas Rekreasi dan Bersosialiasi menunjukkan tingkat harapan yang tinggi dalam menentukan tingkat kepuasan pengguna ruang publik. Diagram IPA menunjukkan bahwa keempat Ruang Publik yang diteliti, telah memberikan performa yang baik didalam mewadahi aktivitas tersebut. Hal tersebut dapat dilihat dari ploting hasil skoring yang berada di atas rata-rata nilai harapan dan kinerja (kuadran B) yang bermakna harus dipertahankan kualitas pelayanannya agar tetap dapat memberikan kepuasan terhadap pengguna ruang publik.

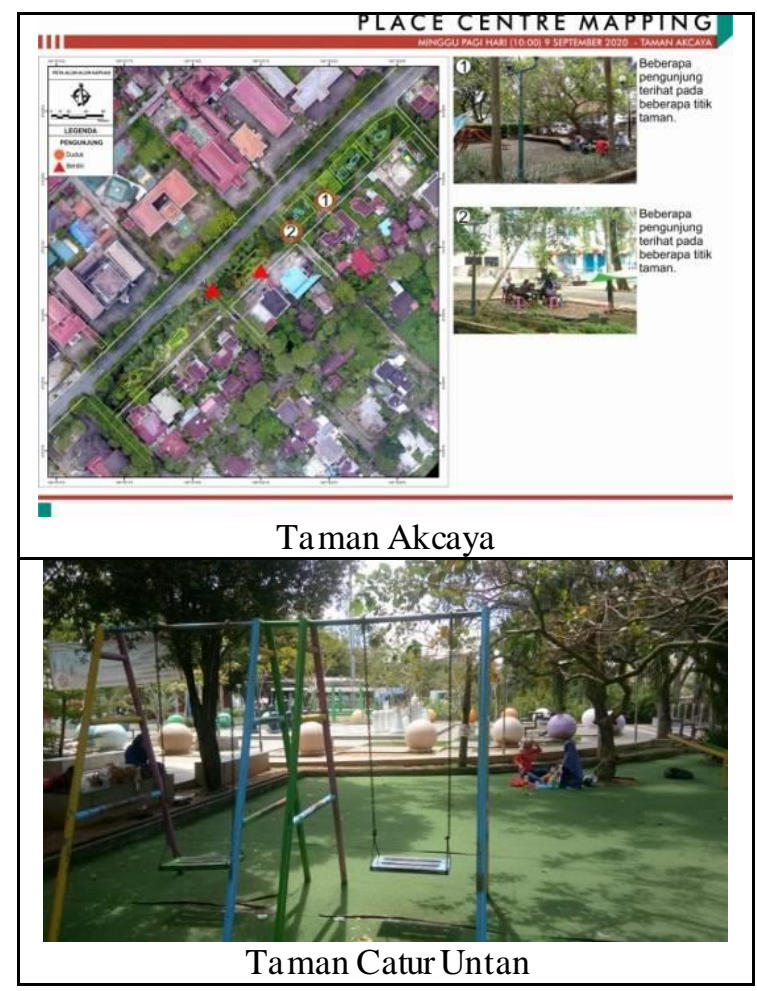

Gambar 1. Aktivitas sosial dibawah teduhan pepohonantaman

Olahraga adalah salah satu cara untuk menjaga dan meningkatkan kualitas kesehatan. Aktivitas fisik di luar ruangan masih diperbolehkan dibeberapa dengan menerapkan physical distancing (Susanto, 2020). Terlebih dalam masa pandemi Covid 19, menjaga daya 
tahan tubuh dengan berolahraga manjadi salah satu trend dikalangan masyarakat (Hadi, 2020). Tingkat Kinerja yang tinggi juga terlihat dari hasil analisis IPA terhadap bagaimana pewadahan aktivitas berolah raga. Tingkat harapan yang tinggi terhadap pewadahan aktivitas berolahraga, hanya ditemukan di Jogging Track Untan dan Taman Akcaya Kota Baru, sedangkan dua ruang publik lainnya, tingkat harapan pengunjung cenderung berada di bawah nilai rata-rata. Hal tersebut bermakna bahwa, Jogging Track Untan dan Taman Akcaya harus dapat mempertahankan kinerjanya didalam mewadahi aktivitas berolah raga pengunjung untuk menjaga tingkat kepuasan yang sudah baik. Sedangkan untuk Taman Alun Kapuas dan Taman Catur Untan, faktor tersebut tidak menjadi hal utama yang sebagai penentu kepuasan pengunjung, meskipun kinerjanya sudah baik.

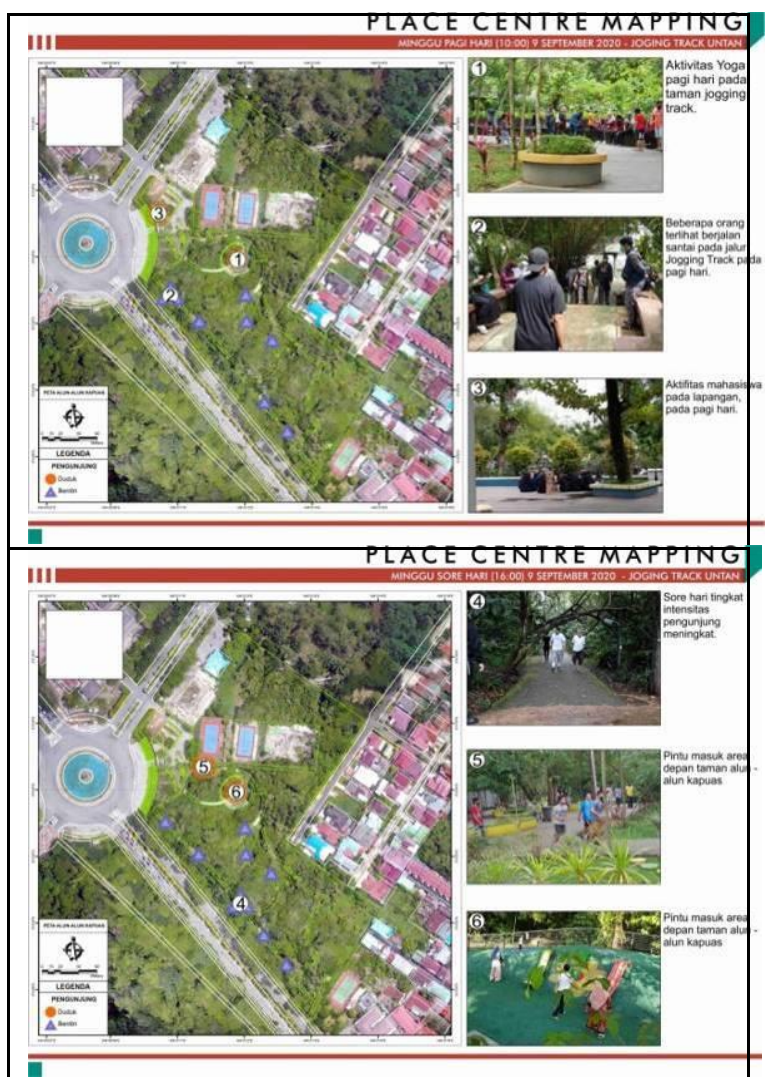

Gambar 2. Aktivitas berolahraga di Jogging Track Untan

Tingkat harapan yang tinggi dalam pewadahan sebagai fasilitas olahraga, cenderung diikuti dengan tingkat harapan yang tinggi pula untuk tingkat harapan pewadahan sebagai ruang aktivitas sosial (rekreasi/ santai) serta harapan dimana ruang publik memiliki ruang hijau dan vegetasi yang cukup untuk meningkatkan kualitas udara. Hal tersebut tercermin dari hasil observasi yang menunjukkan bahwa aktivitas berolahraga biasanya juga diikuti oleh aktivitas sosial seperti berkumpul dan berolahraga bersama (berkelompok) dan memanfaatkan zona teduhan di bawah pepohonan taman. Dari hasil analisis IPA, diketahui bahwa pewadahan kegiatan berolahraga; bersosialisasi; dan keberadaan ruang hijau merupakan faktor yang dianggap sangat penting dan dinilai sudah memuaskan pengunjung.

Dalam aktivitas Rekreasi, sosialisasi dan berolahraga, penerapan kebiasan baru seperti menjaga masker dan mencuci tangan menjadi hal yang penting, sehingga perlu peningkatan terhadap akses kepada fasilitas safe water, sanitation and hygiene (WASH) untuk cuci tangan sebagaimana telah disarankan oleh WHO (2020b). Berdasarkan analisis IPA, keberadaan fasiltas mencuci tangan di keempat Ruang Publik yang diteliti menunjukkan tingkat harapan yang tinggi, tetapi masih belum memuaskan pengguna ruang publik. Satu unit tempat cuci tangan di Taman Akcaya dan dua unit di Joging Track Untan terindikasi masih kurang dalam mewadahi aktivitas mencuci tangan 


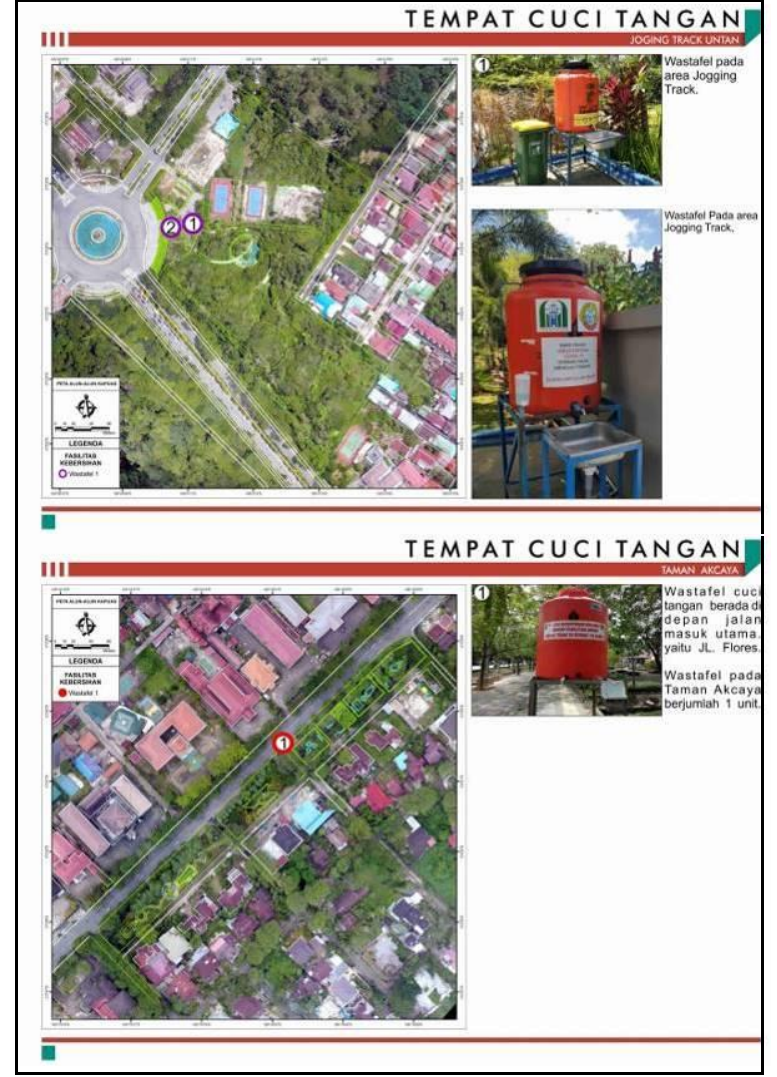

Gambar 3. Fa silita s Cuci tangan di Jogging Track Untan dan Taman Akcaya Kota Baru

Begitu juga halnya dengan 4 titik tempat cuci tangan di Taman Alun Kapuas dan tiga titik tempat cuci tangan di Taman Catur Untan, masih belum dapat memuaskan harapan pengunjung terhadap aktivitas mencuci tangan, terutama dalam kondisi pandemi Covid 19 ini. Hal tersebut dapat dilihat dari ploting tingkat harapan dan kinerja berada di kuadran A, yang artinya pengelola Ruang Publik perlu untuk meningkatkan pelayanan dengan menambah kecukupan dan ketersediaan fasilitas cuci tangan.

Akses Internet gratis manjadi salah satu fakt or yang menentukan tingkat kepuasan pengguna ruang publik, khususnya untuk Pengguna Ruang publik di Taman Akcaya Kota Baru dan Taman Digulis (jogging track) Untan. Hasil analisis IPA menunjukkan atribut 'terdapat koneksi internet gratis' berada di kuadran A, yang berarti pengelola belum berhasil memberikan kepuasan terhadap harapan Pengguna, padahal disisi lain, harapan terhadap pemenuhan hal tersebut tinggi dan mempengaruhi tingkat kepuasan pengguna ruang publik. Tuntutan untuk bekerja secara online, memang menjadi pola hidup baru pasca covid. Sesuai pendapat Honey-rosés dan kawan-kawan (2020) aktivitas berbelanja online cenderung meningkat.

\subsection{Physical Distancing di Ruang Publik dengan Mekanisme 'Keterdesakan'}

Pembahasan terkait upaya untuk menjaga dan meningkatkan kesehatan masyarakat lewat aktivitas olahraga dengan diikuti gaya hidup bersih, mencuci tangan dan menggunakan masker seperti yang telah dibahas sebelumnya, menunjukkan kepedulian dan pemahaman masyarakat yang baik terkait upaya pencegahan agar tidak tertular Covid 19. Diskursus terkait terminologi new normal mengemuka belakangan ini. Sebagaimana pendapat Salama (2020), salah satu variabel didalam penerapan kondisi New Normal selain isolasi manusia, dan pemanfaatan teknologi informasi, adalah tindakan Social Distancing.

Istilah 'jaga jarak' merujuk kepada penerapan jarak antar-pribadi guna untuk menghindari penyebaran virus. Berdasarkan hasil survey, regulasi terkait penerapan jarak antar-pribadi dan penerapan protokol kesehatan tersebut telah dilaksanakan oleh Pemerintah Daerah (provinsi dan kota). Hal tersebut dapat dilihat dari keluarnya Pergub Kalbar No 110 (Pemda Prov Kalbar, 2020), yang disosialisasikan juga lewat baliho-baliho dan papan-papan informasi di ruang-ruang Publik ini. Dari baliho yang dipasang, Pemerintah Daerah menerapkan jarak aman yang dianjurkan adalah minimal 1 meter.

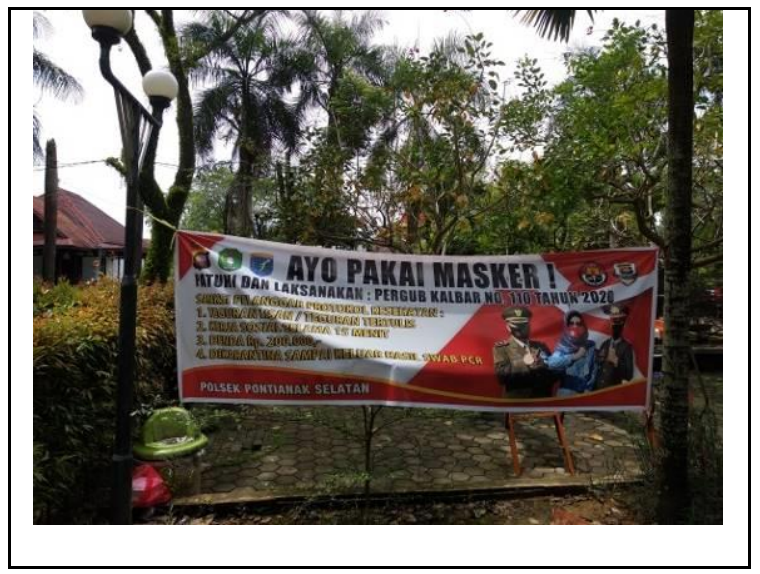




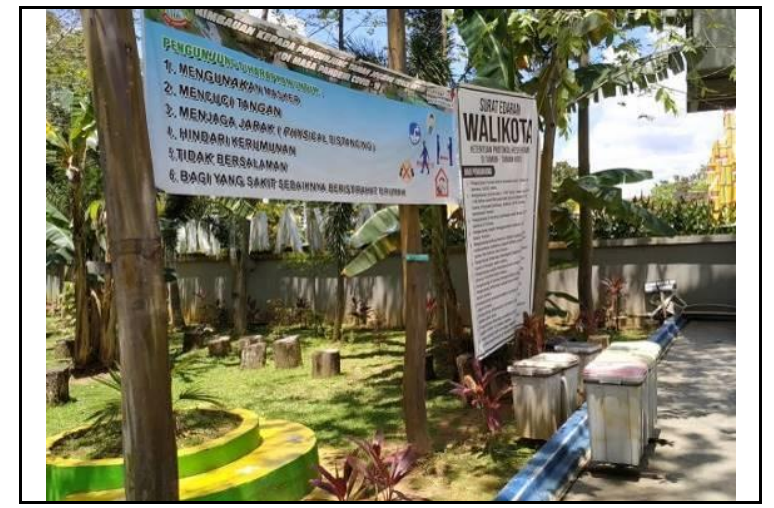

Gambar 4. Sosia liasi Pera turan Pemerintah dan Protokol Kesehatan

Hasil yang didapatkan dari hasil analisis IPA terhadap penilaian Harapan dan Kinerja Ruang Publik yang berhubungan dengan protokol menjaga jarak yaitu 'Ukuran/ lebar jalur pejalan kaki/ trotoar/selasar; Desain dan ukuran bangku/ kursi/ tempat duduk yang memungkinkan protokol jaga jarak, menunjukkan bahwa atribut-atribut tersebut menjadi elemen yang menentukan kepuasan pengguna ruang publik tetapi belum baik kinerjanya. Hal tersebut dapat dilihat dari desain lebar jalur pejalan kaki yang rata-rata lebarnya 1 - 2,5 meter, membuat upaya menjaga jarak masih cukup sulit, apalagi saat aktivitas berolahraga (jogging). Tingkat harapan tinggi dan kinerja yang memuaskan terhadap aspek tersebut hanya ditemui di Taman Catur Untan.

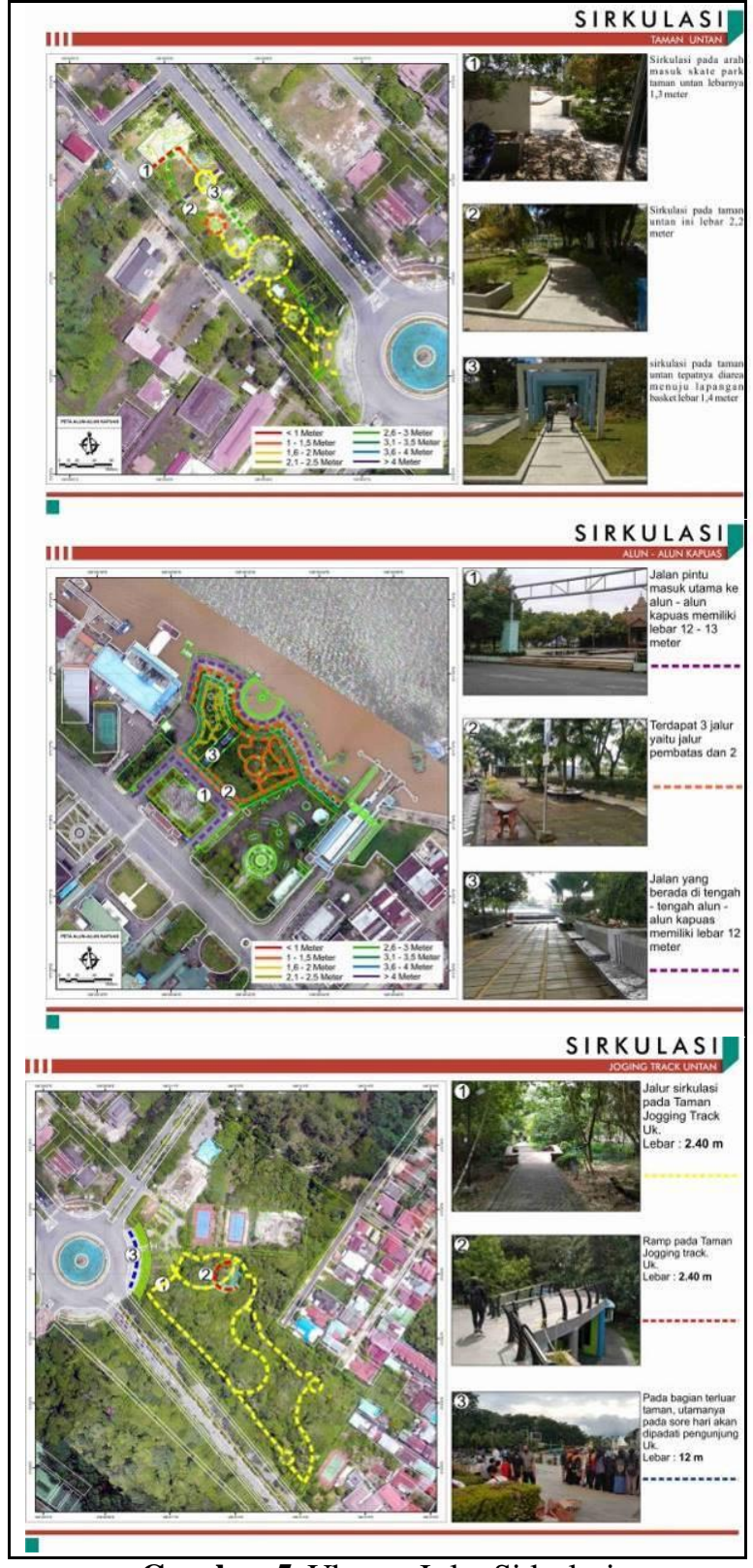

Gambar 5. Ukuran Jalur Sirkulasi

Bangku dan kursi belum di desain secara khusus untuk penerapan jaga jarak. Sebagian kursi dan bangku yang ada, masih menggunakan mekanisme 'tidak permanen' untuk penanda jaga jarak, seperti dengan ditempel plester/ cat/ tanda silang. Sebagian yang lain bahkan belum / tidak memiliki mekanisme jarak duduk antar pengunjung.

Yang perlu digaris bawahi dari protokol jaga jarak adalah, berapa jarak yang optimum dalam mencegah penyebaran virus. Jarak yang disarankan saat beraktivitas di ruang publik untuk menghindari penyebaran virus adalah 1 meter (WHO, 2020a). Tetapi beberapa studi 
juga menyatakan bahwa jarak 1 meter tidaklah cukup untuk mengontrol infeksi virus. Studi tersebut bahkan menyarankan jarak 2 sampai dengan 6 meter jarak aman, karena droplet dapat terbang menjangkau jarak yang sekitar 2 meter tergantung dari ukuran, kelembaban udara dan temperatur (Sun \& Zhai, 2020). Tetapi menurut Rezaei \& Azarmi (2020), WHO juga mendefinisikan jarak minimal antar individu adalah $1,8 \mathrm{~m}$ (6 feet).

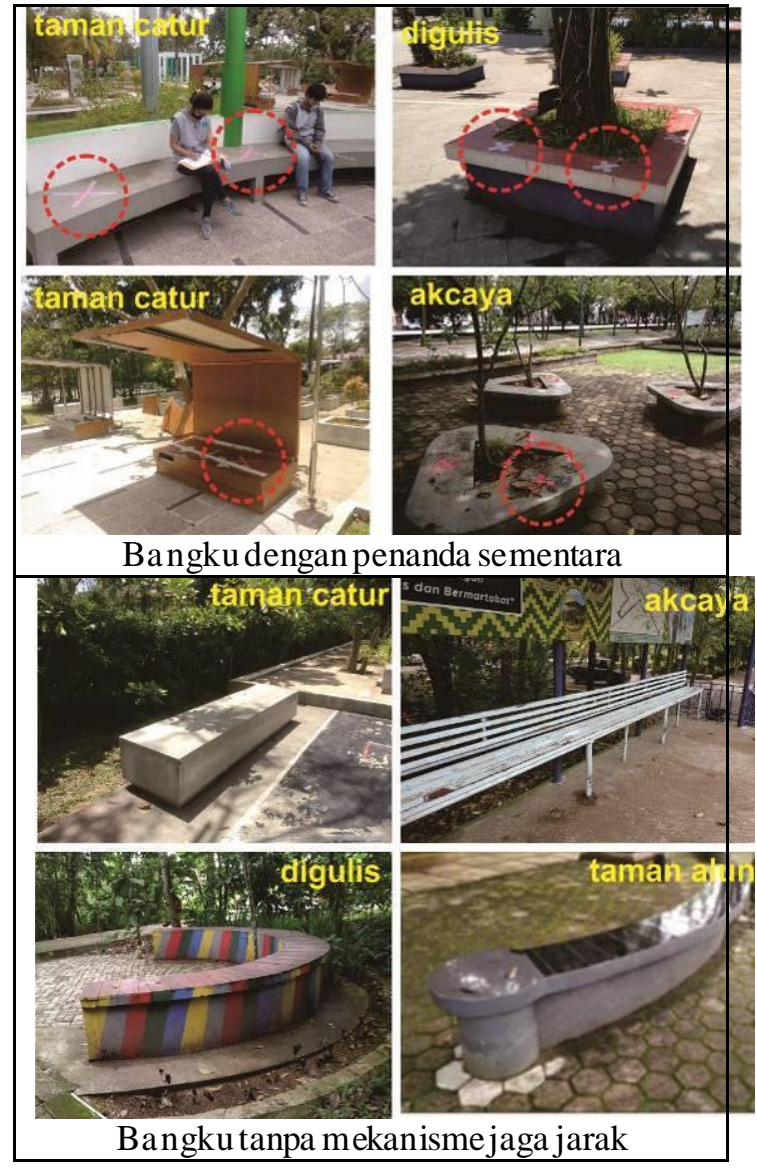

Gambar 6. Mekanisme jaga jarak bangku taman

Dari literatur - literatur tersebut, belum ada ketentuan jarak yang dapat memastikan virus tidak menyebar atau menjangkiti seseorang lewat air bone. Tetapi berdasarkan regulasi yang dikeluarkan oleh Menteri Kesehatan RI dalam (Kementrian Kesehatan RI, 2020), salah satu dari norma baru yang diatur dalam protokol kesehatan adalah menjaga jarak minimal 1 meter. Didalam banner dan spanduk himbauan yang dipasang Pemerintah Kota Pontianak di lokasi penelitian disebutkan bahwa pengunjung ruang publik wajib untuk menjaga jarak minimal 1 meter.

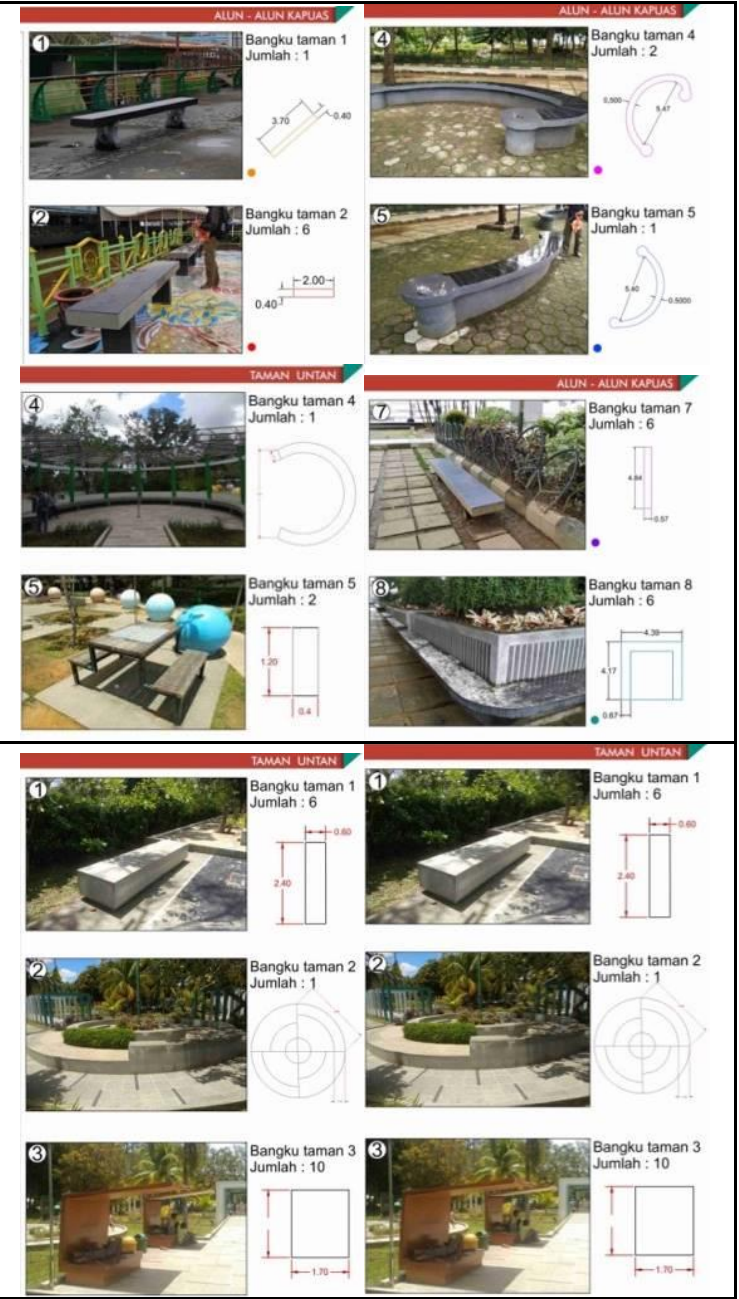

Gambar 7. Ukuran Bangku di Area Penelitian

Selanjutnya yang paling penting adalah menerapkan regulasi tersebut dilapangan. Setiap area yang memungkinkan adanya interaksi dan berkumpulnya orang, harus disediakan sarana yang memungkinkan terjadinya jaga jarak minimal 1 meter tersebut. Area bangku dan kursi, harus di desain sesuai dengan pola kenormalan baru, dengan pengaturan jarak antar pengunjung dan mekanisme yang dapat menghindari penularan dari droplet. Sejak kasus Covid 19 bulan Maret silam di kota Pontianak, penerapan mekanisme jaga jarak untuk desain bangku/ tempat duduk di ruang-ruang publik kota memang baru dilakukan dalam konteks 'keterdesakan', yang dapat dilihat dari penggunaan elemen-elemen tidak permanen/ sementara untuk penanda-penanda jarak pengunjung di bangku-bangku taman. Sehingga dimasa yang akan datang, diperlukan desain yang lebih permanen, agar mekanisme 
jaga jarak dapat tetap dilaksanakan secara konsisten guna meminimalisir penularan virus.

\subsection{Inkonsistensi Tingkat Harapan Dengan Perilaku}

Upaya kontrol cek kesehatan merupakan atribut yang mempengaruhi kepuasan pengguna ruang, tetapi dengan kinerja yang belum maksimal. Dari hasil observasi dilapangan, tidak ada satu pun dari keempat ruang publik yang diteliti menerapkan pemeriksaan kesehatan dan suhu tubuh bagi pengunjung saat memasuki ruang publik. Kontrol terhadap pengunjung yang tidak menggunakan masker juga belum berjalan dengan baik, meskipun telah ada sangsi (administratif atau sosial) bagi yang melanggar.

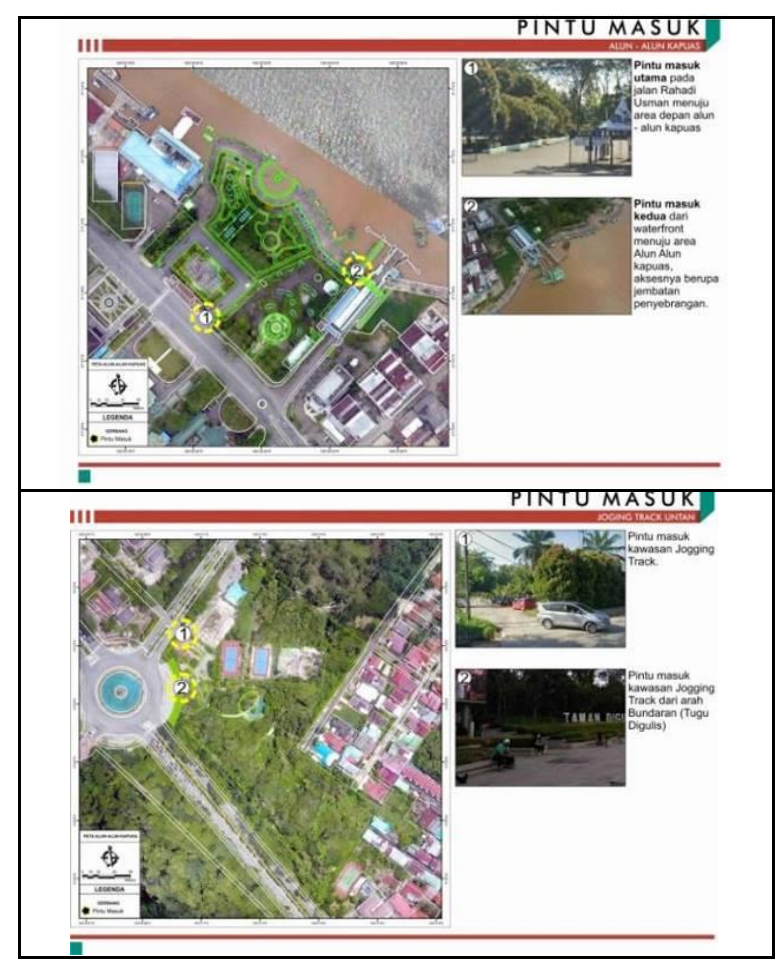

Gambar 8. Pintu Masuk di Taman Alun Kapuas dan Taman Digulis

Untuk kasus taman Alun Kapus dan Taman Digulis, penerapan kontrol kesehatan dan penggunaan masker relatif lebih mudah diterapkan, karena jumlah pintu masuk/ akses yang terbatas, sehingga akan memudahkan operasional pengawasan oleh petugas. Sedangkan untuk kasus di Taman Catur Untan dan Taman Akcaya Kota Baru, penerapan upaya kontrol kesehatan dan penggunaan masker akan memerlukan upaya yang lebih besar, karena akses masuk yang cukup bany ak dan tidak adanya pagar penghalang akses.

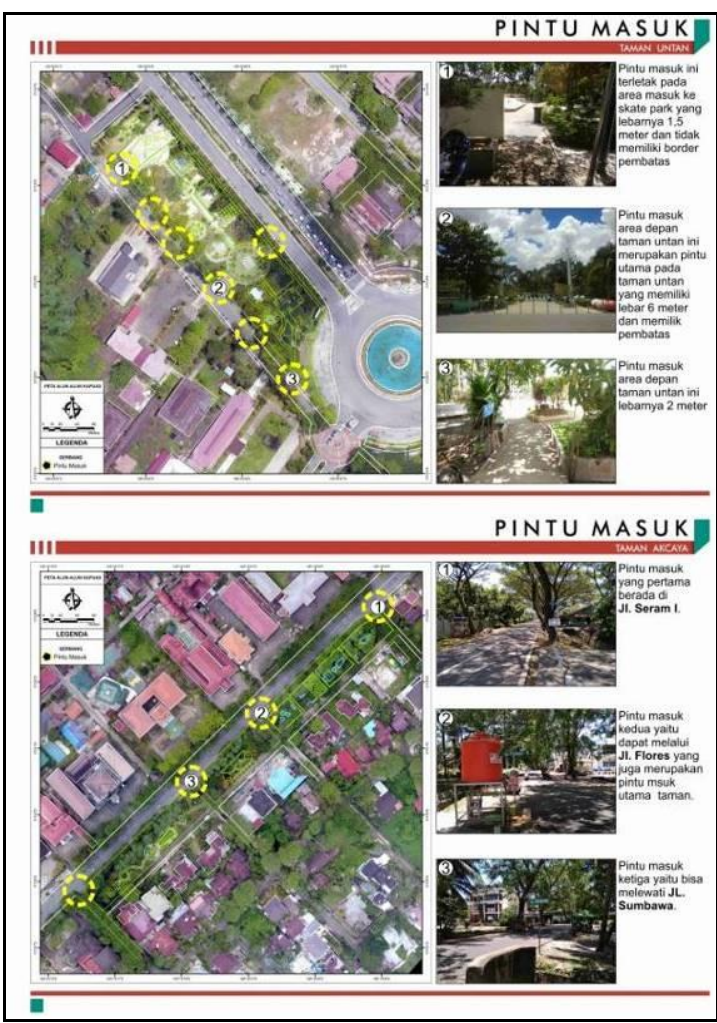

Gambar 9. Pintu Masuk Taman Catur Untan dan Taman Akcaya Kota Baru

Berdasarkan hasil observasi lapangan, protokol kesehatan belum berjalan baik. Dalam beraktivitas, pengunjung terindikasi masih belum optimal jaga jarak minimal 1 meter. Hal tersebut dapat dilihat dari hasil place centered mapping yang menunjukkan masih cukup banyak kerumunan pengunjung yang duduk dan bersosialisasi tanpa menerapkan jaga jarak minimal 1 meter. Bahkan masih cukup banyak pengunjung yang tidak menggunakan masker, walaupun mereka tidak dalam kondisi beraktivitas berat, seperti berolah raga. Hal ini tentu menjadi suatu fakta yang menarik, dimana berdasarkan hasil analisis sebelumnya, dapat dinyatakan bahwa tingkat harapan pengunjung terhadap penerapan protokol kesehatan, seperti mencuci tangan, jaga jarak, kontrol dan cek kesehatan, adalah tinggi. Tapi disisi yang lain dalam aplikasi kesehariannya di ruang publik kota Pontianak masih belum mencerminkan pola kebiasaan baru khususnya dalam menjaga jarak dan menggunakan masker, meskipun telah ada acaman sangsi bagi pelanggar. 


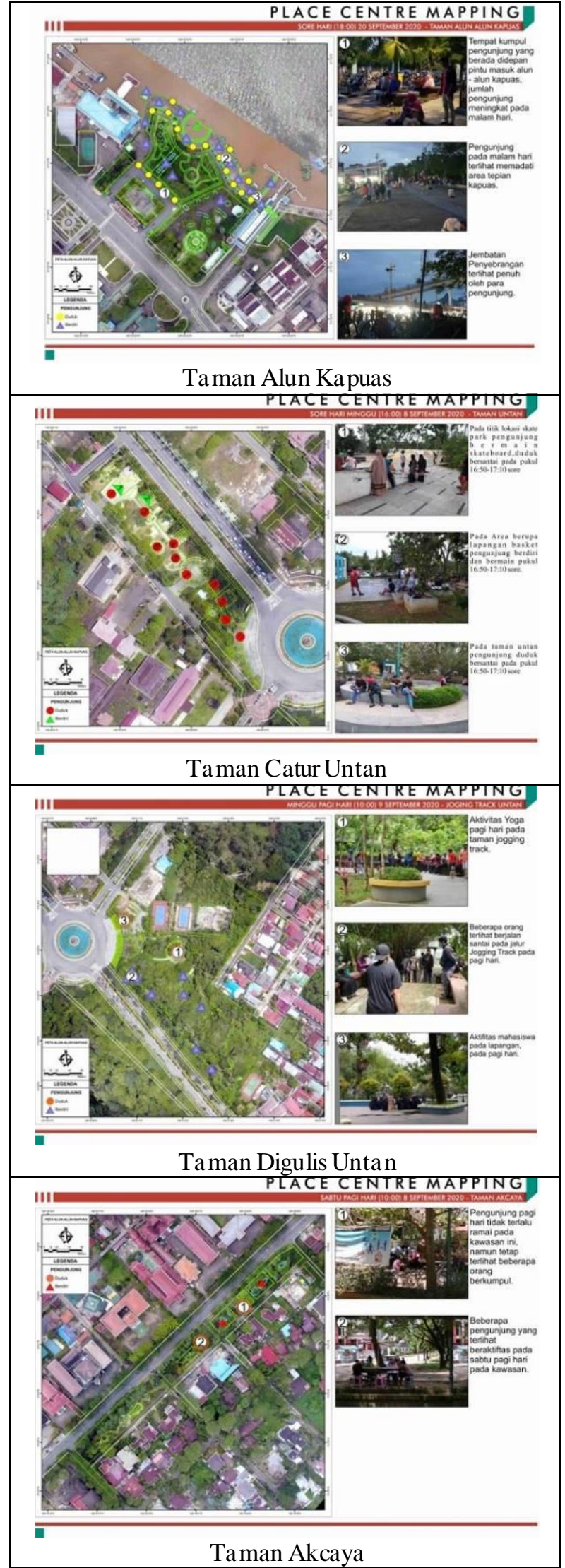

Gambar 10. Aktivitas berkumpul di Ruang Publik

\subsection{Tele-Working/ Tele-Learning Tidak berlaku di Ruang Publik}

Bekerja dan belajar dengan memanfaatkan jaringan Internet menjadi salah satu aktivitas baru yang lazim kita temui dimasyarakat kita pasca Covid 19. Pembelajaran online yang dilakukan sekolah-sekolah di kampus-kampus. Pemanfaatan Portal pembelajaran online untuk guru dan siswa menunjukkan prospek penggunaan IT cukup cerah (Pujilestari, 2020). Tetapi ternyata hal tersebut tidak berlaku di ruang-ruang publik yang diteliti. Berdasarkan hasil Analisis IPA, tersedianya area untuk belajar/ bekerja secara online di Ruang Publik yang diteliti menunjukkan bukan merupakan faktor yang kuat dalam menentukan tingkat kepuasan pengguna.

Atribut tersebut cenderung berada di kuadran C yang menunjukkan bahwa hal tersebut menjadi hal yang tidak terlalu penting dan didalam kinerjanya pun cenderung kurang/ tidak memuaskan. Jika melihat pembahasan sebelumnya, maka dapat dikatakan bahwa aktivitas berolahraga; rekreasi dan bersosialisasi, lebih menjadi pilihan dari pada belajar atau bekerja secara online di Ruang Publik tersebut.

\section{KESIMPULAN}

Berdasarkan Hasil Analisis dan Pembahasan, maka dapat disimpulkan beberapa hal terkait Kesiapan Ruang Publik Kota Pontianak dalam mengantisipasi Kondisi New Normal. Atribut yang menjadi faktor penting yang menentukan kepuasan Pengguna Ruang dan tetapi masih memerlukan peningkatan Kinerja adalah : Kontrol penerapan protokol kesehatan; Kecukupan dan ketersediaan fasilitas cuci tangan.

Keempat Ruang Publik yang diteliti telah memberikan performa yang baik dalam mewadahi Aktivitas Rekreasi dan Bersosialiasi. Hal tersebut dapat dilihat dari ploting hasil skoring yang berada di atas ratarata nilai harapan dan kinerja (kuadran B) yang bermakna harus dipertahankan kualitas pelayanannya agar tetap dapat memberikan kepuasan terhadap pengguna ruang publik. Tetapi pemanfaatan ruang publik untuk aktivitas rekreasi dan sosialisasi harus diikuti 
dengan penerapan protokol kesehatan untuk mencegah penularan penyakit.

Tingkat harapan yang tinggi terhadap pewadahan aktivitas berolahraga, ditemukan di Jogging Track Untan dan Taman Akcaya Kota Baru. Hal tersebut bermakna bahwa, Jogging Track Untan dan Taman Akcaya harus dapat mempertahankan kinerjanya didalam mewadahi aktivitas berolah raga pengunjung untuk menjaga tingkat kepuasan yang sudah baik. Hal tersebut akan memberikan ruang alternatif bagi masyarakat kota Pontianak untuk berolahraga, sehingga meningkatkan kesehatan dan daya tahan tubuh dengan di masa pandemi ini.

Physical Distancing di ruang publik masih dilaksanakan dengan mekanisme 'keterdesakan' tetapi telah diupayakan dengan pemasangan elemen-elemen penanda 'tidak permanen' di bangku-bangku/ kursi, tetapi belum didesain dengan lebih 'serius'. Ukuran lebar jalur pejalan kaki juga belum sepenuhnya memungkinkan protokol jaga jarak. Hal tersebut dapat dipahami, karena desain bangku/ kursi dan jalur pejalan kaki dilakukan sebelum pandemi Covid 19 melanda.

Inkonsistensi Tingkat Harapan Dengan Perilaku. Tingkat harapan pengunjung terhadap penerapan protokol kesehatan, seperti mencuci tangan, jaga jarak, kontrol dan cek kesehatan, adalah tinggi. Disisi yang lain, perilaku Pengguna ruang publik kota Pontianak masih belum mencerminkan pola kebiasaan baru, khususnya dalam menjaga jarak dan menggunakan masker, meskipun telah ada acaman sangsi bagi pelanggar.

Tele-Working/ Tele- Learning tidak menjadi hal yang menentukan kepuasan pengunjung saat berada di ruang publik, ketersediaan area untuk belajar/ bekerja secara online di Ruang Publik yang diteliti menunjukkan bukan merupakan faktor yang kuat dalam menentukan tingkat kepuasan pengguna.

\section{UCAPAN TERIMAKASIH}

Penelitian ini dilakukan dengan dukungan pendanaan dari DIPA Polnep tahun 2020 dalam Penelitian Terapan Polnep.

\section{REFERENSI}

ANTARA. (2020). Taman Alun-alun Kapuas di kota Pontianak ditutup cegah COVID19 - ANTARA News. https://www. antaranews.com/berita/1361 946/taman-alun-alun-kapuas-di-kotapontianak-ditutup-cegah-covid-19

BNPB RI. (2020). Pentingnya Pakai Masker untuk Melindungi Orang Lain - BNPB. https://bnpb.go.id/berita/pentingnyapakai-masker-untuk-melindungi-oranglain

Creswell, John W; Plano Clark, V. L. (2007). Designing and Conducting Mixed Methods Research. Sage Publications, Inc.

Hadi, F. K. (2020). Aktivitas Olahraga Bersepeda Masyarakat Di Kabupaten Malang Pada Masa Pandemi Covid-19. Sport Science and Education Journal, $1(2), 28-36$.

Hanoatubun, S. (2020). Dampak Covid - 19 Terhadap Perekonomian Indonesia. EduPsyCouns Journal, 2, 146-153.

Honey-rosés, J., Anguelovski, I., Bohigas, J., Chireh, V., Daher, C., Litt, J., Mawani, V., Mccall, M., Orellana, A., Oscilowicz, E., Sánchez, U., Senbel, M., Tan, X., Villagomez, E., \& Zapata, O. (2020). The Impact of COVID-19 on Public Space: A Review of the Emerging Questions. 1-20.

Kementrian Kesehatan RI. (2020). Dokumen resmi. In W. Mas'udi; \& P. S. Winanti (Eds.), Pedoman kesiapan menghadapi COVID-19 (pp. 0-115). UGM Press. http://repository.petra.ac.id/18871/1/Publ ikasi1_98030_6562.pdf\#page=54

Martilla, J. A., And, \& James, J. C. (2010). Importance-Per Analysis. The Journal of Marketing, 41(1), 77-79.

Mua, G. P., \& Suheri, T. (2018). Vol.15 No. 2. Majalah Ilmiah UNIKOM, 15(2), 263272.

https://repository.unikom.ac.id/id/eprint/ 56819

Pemda Prov Kalbar. (2020). Pergub Kalbar No 110 Tentang Penerapan Disiplin Dan Penegakan Hukum Protokol Kesehatan.

Pratiwi, Y. (2016). Transformasi Fungsi Ruang Terbuka Publik Di Perkotaan Studi Kasus: Taman Pedestrian Kecamatan Tenggarong, Kabupaten 
Kutai Kartanegara, Kalimantan Timur. NALARs, $\quad$ 15(1), 63. https://doi.org/10.24853/nalars.15.1.6372

Pujilestari, Y. (2020). Dampak Positif Pembelajaran Online Dalam Sistem Pendidikan Indonesia Pasca Pandemi Covid-19. Adalah, 4(1), 49-56. http://journal.uinjkt.ac.id/index.php/adala h/article/view/15394/7199

Rezaei, M., \& Azarmi, M. (2020). Deepsocial: Social distancing monitoring and infection risk assessment in covid-19 pandemic. Applied Sciences (Switzerland), 10(21), 1-29. https://doi.org/10.3390/app10217514

Salama, A. M. (2020). Coronavirus questions that will not go away: interrogating urban and socio-spatial implications of COVID-19 measures. Emerald Open Research, 2(April), 14. https://doi.org/10.35241/emeraldopenres. 13561.1

Sun, C., \& Zhai, Z. (2020). The efficacy of social distance and ventilation effectiveness in preventing COVID-19 transmission. Sustainable Cities and Society, $\quad 62(\mathrm{July}), \quad 102390$. https://doi.org/10.1016/j.scs.2020.102390

Susanto, N. (2020). Pengaruh Virus Covid 19 Terhadap Bidang Olahraga Di Indonesia. Jurnal Stamina, 3(3), 112-119. https://doi.org/10.30701/ijc. 1016

WHO. (2020a). Modes of transmission of virus causing COVID-19: implications for IPC precaution recommendations. In Geneva: World Health Organization; Vol. Available. https://www.who.int/publicationsdetail/modes-of-transmission-of-viruscausing-covid-19-implications-for-ipcprecaution-recommendations

WHO. (2020b). Responding to community spread of COVID-19 (Issue March, pp. $1-6)$.

WHO. (2020c). Strengthening Preparedness for COVID-19 in Cities and Urban Settings. 